\title{
3. A Compelling Case for Chinese Monetary Easing
}

Guonan $\mathrm{Ma}^{1}$

\section{Introduction}

This chapter makes a strong case for Chinese monetary policy easing, contributing to the debate over whether China's latest monetary policy shift is warranted and desirable. Chinese monetary policy was excessively tight in 2014 but started loosening more meaningfully from late 2014, in an attempt to cushion growth, facilitate rebalancing, support reform and mitigate financial risk.

There are three main reasons justifying this shift in monetary policy stance. First, there is evidence that the Chinese economy has been operating below its potential capacity. Second, among the big-five (G5) economies, both China's monetary policy stance and its broader financial condition tightened the most in the wake of the global financial crisis (GFC). This weighed on Chinese domestic demand. Third, a mix of accommodative monetary policy and neutral fiscal policy would serve China the best now, as the country opens up its capital account and moves away from its dollar peg, while restructuring its local government finance.

However, such a warranted shift in monetary policy faces challenges of uncertain potential growth, a more liberal financial system, an evolving monetary policy framework, a legacy of excess leverage and a politicised policy debate.

The rest of the chapter is organised as follows. Section two highlights the two competing schools of thought in the heated debate over Chinese monetary policy that took place in mid-2014. Sections three to five lay out the three arguments for monetary policy easing: a Taylor rule perspective, a global perspective and an optimal monetary policy mix perspective. Section six concludes, suggesting that a timely and sensible monetary accommodation could be the best course of policy action for China in terms of growth, reform, rebalancing and financial stability.

1 The views expressed in this chapter are those of the author only and not of the affiliated institutions. The author wishes to acknowledge Warren $\mathrm{Lu}$ for his excellent research assistance. Any errors are mine. 


\section{The Chinese monetary policy debate}

Monetary policymaking can be tough and controversial, as illustrated by discussions about whether and how the European Central Bank (ECB) ought to pursue quantitative easing (Claeys et al. 2014), and whether and when the US Federal Reserve (US Fed) should start normalising.

Similar discussions started heating up in mid-2014 about China's monetary policy stance (Ma 2014a). They centred on whether Chinese monetary policy was excessively tight at that time and thus ought to ease in a timely and meaningful way. From late 2014, the People's Bank of China (PBC) started to act more decisively to ease its monetary policy - most notably, its three rate cuts and another broad reserve requirement ratio (RRR) cut during late 2014 and early 2015. Did the PBC make a big policy mistake, perhaps by succumbing to political pressure from vested interests? The short answer is no, and the rest of this chapter will make a case for Chinese monetary accommodation.

This policy debate also broadened, sometimes in a confusing manner, to encompass the related question of whether China should persist with painful but eventually rewarding economic reform or ease monetary policy to stabilise growth.

There are two views on this (Sina Finance 2014). One camp believes that monetary accommodation hampers economic reform, worsens structural imbalances in the Chinese economy and promotes unsustainable short-term pseudo-growth at the expense of sustainable long-term development. This camp's main arguments appear to be that reforms and structural adjustments are necessarily painful and that the recent economic slowdown is simply structural and healthy. According to this view, demand-side factors matter little in the recent Chinese growth slowdown. Thus, an accommodative monetary policy is unwarranted and at odds with reform and restructuring. Instead, monetary easing is not only a show of no confidence in reform but also an attempt to sabotage reform. In short, no pain, no gain.

The less ideologically driven argument points to a still buoyant Chinese labour market in spite of weaker growth as evidence of an economy near its lower growth potential. A shrinking Chinese labour force, a possible Lewis turning point, a bigger job-intense service sector and the attendant slower total productivity growth might all combine to trim underlying growth potential consistent with non-inflationary full employment (Ma et al. 2012). Therefore, slower headline gross domestic product (GDP) growth can still be compatible with an economy operating at or near full capacity, questioning any need for monetary accommodation. Such concerns are valid and will be addressed in this chapter. 
The opposite, pro-easing camp thinks that sensible, nimble monetary easing complements economic reform, cushions growth, facilitates structural adjustment and mitigates financial risk. Reform, while imperative, is not a sacred cow but a means to improve living standards for the majority of the Chinese population. And economic reform calls for a sensible shift in the monetary policy stance in response to business cycles. The Chinese economy is unbalanced, but one does not need to strangle it in order to rebalance it. On the contrary, an excessively tight monetary policy could aggravate structural imbalances.

According to the easing camp, the Taylor rule, the global beauty contest of monetary easing among the G5 central banks - the US Fed, the PBC, Bank of Japan (BoJ), ECB and Bank of England (BoE) - and the Mundell-Fleming model all suggest an excessively tight monetary policy stance for most of 2014, and thus a need for a meaningful Chinese monetary relaxation. Both cyclically and structurally, the case for timely and measured monetary accommodation is compelling.

This controversy in China looks odd, especially when viewed through the lens of the United States, the euro area and Japan, where the consensus view among policymakers is that aggressive demand-support policy measures and strong structural reforms on the supply side should go hand-in-hand. And why not? The puzzling question is why one should have to make a stark choice between them instead of sensibly combining the two. A healthy Chinese economy needs both structural reforms on the supply side to enhance potential growth and a nimble monetary policy to exploit potential and mitigate possible cyclical headwinds on the demand side.

It is important to note that this debate takes place in a wider domestic and international context that includes issues such as diverging global monetary policies, volatile cross-border capital flows, slower domestic economic growth, falling domestic inflation, painful economic rebalancing, a gathering pace of financial liberalisation, signs of increased financial stress and an evolving monetary policy framework. So we first briefly sketch this background before discussing the debate itself.

After three decades of double-digit growth from 1980 to 2010, the Chinese economy embarked on a transition to a new phase of its development in the wake of the GFC (Ma et al. 2012). This transition features a slower pace of growth, a shrinking current account surplus and a service sector in the process of catching-up. GDP growth slowed from 10 per cent averaged during 2000-10 to 8 per cent during 2011-14, and is expected to decelerate further, to 7 per cent in 2015, while the current account surplus fell from 10 per cent of GDP in 2007 
to 2 per cent in 2014. Such external rebalancing is attained mostly through an even more lopsided internal imbalance of a higher investment ratio and rising leverage.

In the midst of the heated monetary policy debate, the PBC, since mid-2014, has started loosening its monetary policy, initially tentatively and then more forcefully. Is such a policy shift warranted and desirable? I will make a strong case for meaningful Chinese monetary easing based on the following three arguments.

First, the standard Taylor rule suggests an excessively tight Chinese monetary policy stance for most of 2014. Second, after the GFC, the PBC's monetary policy stance tightened the most among the G5 central banks, and Chinese financial conditions also became most restrictive among these economies. Third, the classical Mundell-Fleming model suggests a sensible mix of accommodative monetary policy and neutral fiscal policy, as China is moving towards greater currency flexibility, incremental capital opening and tighter local fiscal conditions.

\section{A Taylor rule perspective}

First, we look at the case for monetary easing in terms of inflation, output and financial stability objectives within the standard Taylor rule framework. There is broad consensus among economists that Chinese growth has been losing momentum in recent years (Figure 3.1). There have been clear signs of rising inventories, slumping property sales, falling consumer price index (CPI) inflation, deepening producer price deflation, weakening corporate earnings, slowing investment and anaemic industrial production. Fortunately, private consumption is still holding up-but just barely-and could show early signs of weakening. If anything, some market commentators even suspect that the Chinese official headline GDP numbers overstate the underlying growth momentum (Nakamura et al. 2015).

An immediate question therefore is if Chinese monetary policy was too tight for most of 2014, relative to what was it too tight? 


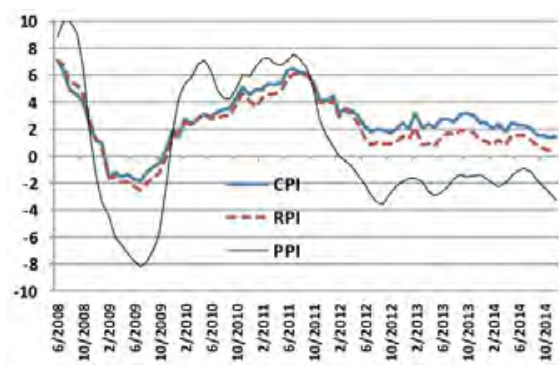

Inflation rates (YoY \%)

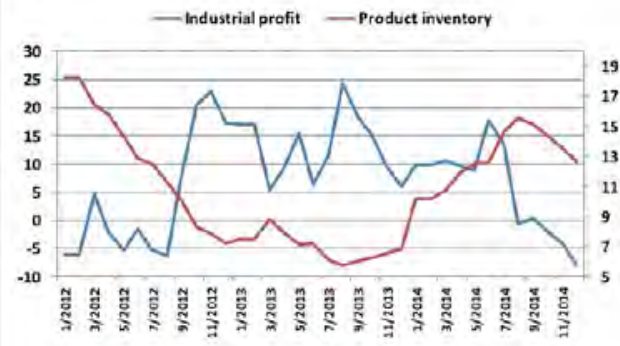

Industrial profit and inventory (YoY \%)

Figure 3.1 Chinese inflation, industrial profit and inventory

Source: CIEC.

As a starting point, most economists and central bankers use the well-known Taylor rule to assess the central bank's policy stance (Taylor 1993). A standard Taylor rule essentially links a short-term nominal policy rate to two gaps for a given inflation target and real long-run equilibrium interest rate consistent with trend growth: the gap between actual and targeted inflation ('the inflation gap') and the gap between actual and potential output ('the output gap'). A positive output or inflation gap, or both, suggests a need to tighten by hiking the policy rate. If the actual policy rate is below that implied by the Taylor rule, the policy stance is considered too accommodating. If the actual policy rate is above that implied by the Taylor rule, the policy stance is considered too restrictive.

In reality, many factors help to shape this 'Taylor rate' - hence the controversy in China over how tight the PBC's monetary policy was before the latest monetary relaxation. In light of this, three useful questions can be highlighted. What weight does the $\mathrm{PBC}$ attach to inflation? Has the Chinese economy been operating near full capacity? How should one gauge the PBC's monetary policy stance?

First, how important is inflation relative to other policy objectives? The PBC is officially not of inflation targeting type, flexible or otherwise. The 1994 Chinese central bank law explicitly stipulates four policy objectives for the PBC: price stability, employment, economic growth and balance of payments. In practice, financial stability and credit allocation are also high on the PBC's agenda. However, Girardin et al. (2014) estimate the PBC's monetary policy reaction function and conclude that inflation has been given greater weight relative to output from the 2000s. This was more so after the start of Zhou Xiaochuan's governorship of the PBC in 2001.

Chinese CPI inflation fell noticeably - from an average 2.5 per cent in 2013 to 2.2 per cent in the first half of 2014, and to 1.8 per cent in the second half of 2014, below the official 2014 target of 3.5 per cent. It even sank to about 1 per cent in the first quarter of 2015 - the lowest level in five years. Retail prices also paint 
a broadly disinflationary picture. Producer prices have even registered outright and persistent deflation for more than two years (Figure 3.1). The pronounced disinflationary pressure emerged well before the collapse of international oil prices starting from the third quarter of 2014. Inflation in China is probably now too low for comfort. According to the Taylor rule, therefore, the PBC ought to ease monetary policy, all other things being equal.

Indeed, the intensified disinflation or even outright deflation pressure since early 2014 helped push up real interest rates even as the nominal policy rate stood still at a time of weakening growth. The first half of 2014 even witnessed rising nominal Chinese government bond yields. One can debate whether the deflation pressure is good or bad, but by doing nothing the PBC would imply a de facto tightening of its monetary policy, which might have contributed to slower economic growth on the demand side beyond what is justified by the structural trends on the supply side.

Second, is the Chinese economy operating near full employment or potential? This is a tricky question. The recent economic slowdown might simply reflect lower potential growth, which could arise from rebalancing pains, demographic headwinds, less low-hanging fruit in market liberalisation and a less accommodating global economy (Ma et al. 2012). Unfortunately, Chinese growth potential, while likely trending lower, is not directly observable, and estimates of it can be elusive and have big margins of error (Blagrave et al. 2015; Ma and Hong 2015; Morley 2014). Some Chinese labour statistics seem to suggest that employment has held up well, as wages are still rising. Thus, weaker growth might not necessarily imply a widening negative output gap and rising unemployment, and hence there would be no case for policy easing.

In the absence of more consistent, reliable and accurate estimates of the underlying Chinese potential growth rate, what can help inform us about the likely output gap? The persistent and intensifying disinflationary and even deflationary pressures at a time of marked deceleration of economic growth are the most telling signs that the Chinese economy is operating well below its potential capacity. It adds to the already high real corporate debt burden, especially for Chinese manufacturing borrowers.

Nevertheless, rapid wage hikes and an apparent lack of corporate pricing power could also combine to hurt corporate earnings, resulting in declining returns on capital and thus weaker private investment spending. Rising real interest rates will tend to punish the most productive and interest rate-sensitive sector in the Chinese economy - small, private firms - as well as consumers. Thus, lower rather than higher nominal and real interest rates are warranted. 
Moreover, it is not clear whether the reported buoyancy of the headline Chinese job market is mainly in the unskilled segment or the broader labour market. Labour market data are known to be the weakest link in Chinese statistics (Amstad et al. 2014; Ma et al. 2012). In addition, the starting salary for Chinese university graduates has been stagnant in recent years. Further, the latest Chinese Purchasing Manager Index (PMI) employment subindex shows early cooling signs in the labour market. In fact, the first quarter of 2015 saw a sharp slowdown in new non-farm jobs. One might reasonably expect a much softer Chinese labour market for the rest of 2015. Therefore, monetary policymakers ought to anticipate rather than wait, as it takes a few quarters for monetary policy actions to affect the labour market.

Whichever way one argues, slower potential economic growth should ultimately point to a lower real equilibrium or natural rate of interest, as assumed by the Taylor rule. Yet, oddly, what we witnessed was rapidly rising real borrowing costs for Chinese firms and home buyers amid slowing growth, until the PBC acted more decisively to ease its policy stance from late 2014 (Figure 3.2). This rise in the 'risk-free' interest rate was the combined result of falling inflation and rising government bond yields: between 2012 and mid-2014, the 10-year Chinese government bond yield rose from 2.5 per cent to 4.5 per cent, as CPI fell from 4 per cent to 2.5 per cent. Therefore, a less stringent monetary policy stance is called for, whether the recent growth slowdown is structural or cyclical.

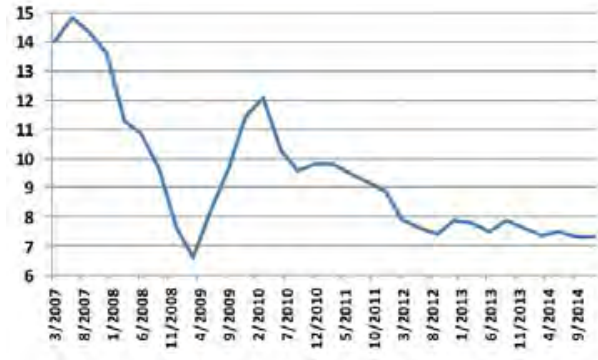

Real GDP growth rate (YoY \%)

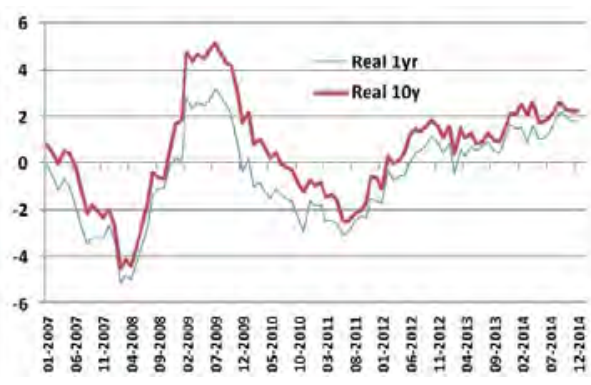

Real Chinese treasury yields (\%)

Figure 3.2 Real Chinese GDP growth and government bond yields Sources: Bloomberg and CEIC.

In short, on the grounds of both the inflation gap and the output gap, the Taylor rule recommends a shift towards a less restrictive monetary policy stance.

This case would have closed, unless financial stability concerns rank higher on the PBC's agenda. An interest rate that is too low could fuel unsustainable shadow banking expansion, excess leverage and asset price booms. China has experienced a massive credit binge since 2007, with total credit to the non- 
financial private sector, including the rapidly expanding shadow banking sector, rising from 120 per cent of GDP in 2007 to 180 per cent in 2014 (Figure 3.3). If central and local government debts are included, the overall leverage in China could approach 250 per cent of GDP. Thus, an excessively loose monetary policy could potentially add to the already growing financial imbalances.

Nevertheless, excessively tight monetary conditions could also run the risk of disorderly deleveraging. First, our knowledge about the effects of monetary policy on financial stability is still limited, which may involve complex dynamics of intertemporal cost-benefit trade-offs (Ajello et al. 2015; Svensson 2015). Second, macro-prudential measures rather than monetary policy might be a better instrument to deal with financial stability issues in most cases (Claeys and Darvas 2015). Third, as nominal GDP slowed from the 15-20 per cent range in the 2000s to some 10 per cent this decade and below 8 per cent lately (Figure 3.3), an excessively restrictive monetary policy could aggravate the already rising debt-service pressures rather than mitigating them and indeed could instigate a dangerous debt deflation spiral.

In any case, while the standard Taylor rule is silent on the weight placed on financial stability relative to that on both output and inflation, the increased financial stress, as witnessed by rising non-performing loans, more credit events and increased last-minute bailouts of troubled borrowers, intuitively calls for a more accommodative monetary policy to assist the tricky deleveraging process. Sticking to a tight policy in the face of increased financial fragility makes little sense.

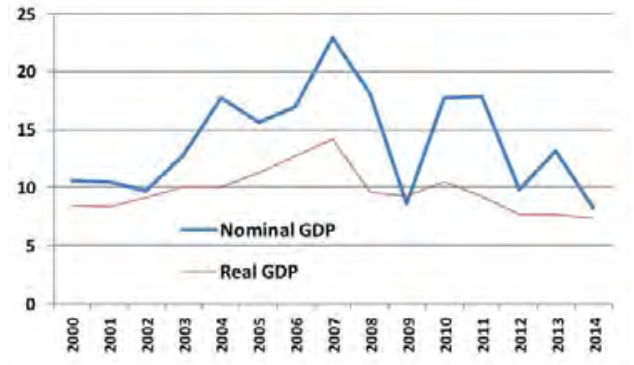

Annual GDP growth (\%)

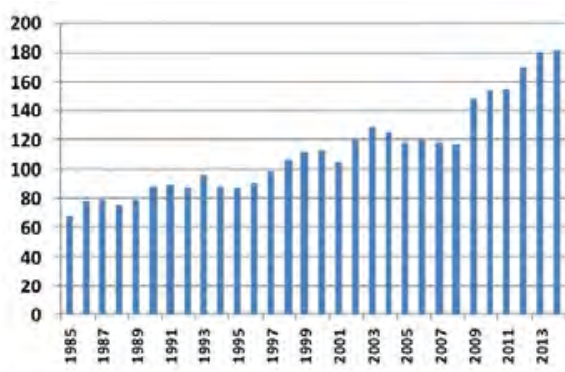

Non-financial private sector debt (\% of GDP)

Figure 3.3 Nominal and real GDP growth and private-sector debt in China Sources: BIS and CEIC.

Third, how can one tell whether the PBC has in fact loosened its stance or not? Gauging the Chinese monetary policy stance is far from straightforward (Girardin et al. 2014; Ma et al. 2012). Essentially, the PBC has pursued a threepronged target of money supply, interest rate and exchange rate, defying any simple interpretation of its policy stance. Also, in contrast with most central 
banks in advanced economies, its policy rate is but one of many instruments in the PBC's toolkit. The PBC traditionally deployed multiple tools, including window guidance, soft loan quotas, regulatory rules, reserve requirements, issuance of $\mathrm{PBC}$ bills, open market operations, relending and interest rates, both market and administered - the interactions of which could reinforce or offset the policy effect (Ma et al. 2012).

Moreover, for most of 2014, the PBC shunned most of its traditionally favoured instruments and instead experimented with new policy tools. It suspended new issuance of PBC bills altogether from the end of 2013, stopped conducting regular open market operations for more than a year, and tested a few new weapons in its arsenal-probably in an attempt to influence market-based interest rates in an environment of volatile two-way capital flows and more liberalised interest rates. $^{2}$ The pros and cons of these new instruments aside, most $\mathrm{PBC}$ watchers find it harder than before to read its underlying monetary policy stance.

Further, the $\mathrm{PBC}$ often communicates its policy stance in a confusing manner. Its policy statements are opaque and difficult to decode even for seasoned PBC watchers. The PBC has a history of intentionally surprising and sometimes even misleading the market, which should be taken as a sign of low confidence on the part of the Chinese central bank. While many Organisation for Economic Cooperation and Development (OECD) central banks now provide 'forward guidance' to reinforce and amplify the impact of monetary policy on the full market yield curve, by communicating to the public about the expected future path of the policy rate, the PBC often appears to dilute what it has just done, by issuing puzzling 'backward guidance', cautioning the market not to interpret its latest rate and RRR cuts as monetary easing (Ma 2015).

Nevertheless, the signs of monetary easing since mid-2014 have been numerous and beyond doubt. Initially, the PBC selectively lowered its RRR and extended loans to small banks and policy banks via its refinancing facilities. It has even leaned on commercial banks to lend more to first-time homebuyers at official mortgage rates. Liquidity has also been injected via its new facilities in an apparent attempt to keep a lid on interbank interest rates. From late 2014, the PBC finally acted more decisively, by cutting outright benchmark bank deposit and lending interest rates as well as the RRR. Some of these belated moves aimed to offset the tighter domestic liquidity arising from increased dollar outflows and thus may not be as expansionary as they look. Nevertheless, in combination, these moves must be interpreted as meaningful monetary relaxation.

2 The PBC has in less than two years introduced and tested a number of new policy instruments, such as 'short-term liquidity operations', the 'standing lending facility', 'medium-term lending facility', 'pledged supplementary lending' and 'pledged relending'. A detailed discussion of the pros and cons of these new tools is beyond the scope of this chapter. 
The PBC can be more forthright in communicating its desire to hit lower and steadier short-term or even mid-term rates, paving the way for the transition to a new monetary policy regime. A clear and firm PBC policy signal could also help flatten and stabilise the Chinese yield curve, which matters more for investment and consumption decisions. As a minimum, the $\mathrm{PBC}$ should avoid diluting the signalling effect of its own new policy moves.

Also, lowering the benchmark 18.5 per cent RRR would help nudge down long yields by adding permanent liquidity into the system and offsetting the tightening effect of the capital outflows seen in the fourth quarter of 2014 and the first quarter of 2015, and would also go some way towards mitigating distortions and containing shadow banking by bringing some off-balance-sheet lending back onto the books. Failures to sterilise capital outflows would result in de facto monetary tightening at a time of weakening growth and falling inflation.

More importantly, by acting swiftly and decisively, the $\mathrm{PBC}$ can be in a stronger position to tighten again when the cycle turns.

Monetary policy measures need to be taken early in order to counter the headwinds that the Chinese economy faces, because it typically takes two to four quarters for a change in policy stance to take effect. Indeed, timely policy response is the best way to avoid excessive monetary stimulus. Some academics and investors tend to underappreciate the fact that the mind-boggling credit binge in late 2008 - mostly related to local government borrowing - was in part a poor response to the already emerging panic partially triggered by the late monetary policy actions at that time (Tanaka 2010). Much of this belated, massive monetary expansion funded quasi-fiscal spending rather than helping cushion the Chinese economy via standard channels, so this time, China ought to ease in a timely way.

To sum up, in light of growth, inflation and financial stability, the standard Taylor rule suggests that China ought to ease its monetary policy in a timely and confident manner.

\section{A global perspective}

So far, this chapter has made a domestic case for monetary relaxation, as the discussion has been framed mostly within a closed-economy version of the Taylor rule. Can a similar case be made for Chinese monetary relaxation from a global perspective? While China's capital control still binds (Ma and McCauley 2008,2013 ) and central banks set monetary policy mainly to cater for domestic needs in most economies, the question is still meaningful, because China is the 
top trader, second-largest economy and third-largest creditor nation globally. Of course, China, known for its export-led growth model, hardly qualifies as a closed economy.

Reserve Bank of India Governor Raghuram Rajan recently raised concerns about the international spillovers from 'competitive monetary easing' among major central banks (Rajan 2014). Rajan's concerns make sense. By definition, the world is a closed economy and is often dominated by a few major central banks that behave more like price setters than price takers. 'Price' in this context used to be some benchmark short rate only, but in the wake of the GFC it also included the fuller yield curve. Thus, strong policy measures taken by major central banks ought to produce global repercussions.

This, in turn, poses the interesting question of how loose or tight China's monetary policy might be relative to its major international peers. In particular, how did the PBC fare in the global race towards monetary accommodation after the GFC? Has the PBC outdone its global peers in the monetary loosening game? This is a question of global perspective, and there is no better benchmark than the club of the central banks that issue the four constituent currencies of the International Monetary Fund (IMF) Special Drawing Rights (SDRs): the Fed, the ECB, BoJ and BoE.

We know that most of these major central banks have substantially expanded their balance sheets in recent years (Iwata and Takenaka 2012). We also know that China has experienced a massive credit binge since 2007. However, to assess the relative monetary policy stances of these four major central banks and the PBC, we need to compare apples with apples more directly.

One way to do so is to look at two key price indicators - the real policy rate and the real effective exchange rate - taking into account three considerations. First, the Taylor rule suggests that the real policy rate should relate to the deviation of actual from target inflation, the output gap and the short-term rate consistent with non-inflationary full employment. Second, the best measure of the global strength of a currency is the real effective exchange rate. Third, these two price indicators interrelate and define the two core aspects of a central bank's monetary policy operations and stance.

Both the real policy rate and the real effective exchange rate used here are ex post. I define the real policy rate as the policy rate less concurrent CPI inflation. I also use the CPI-based real effective exchange rate compiled by the Bank for International Settlements (BIS). To examine the relative monetary policy tightness of the G5 central banks since the GFC, I focus on the period between January 2007 and March 2014 before the PBC finally started easing and the US Fed hinted at normalising. 
The left-hand panel of Figure 3.4 shows that all G5 central banks except the PBC have negative real policy rates. Indeed, the US Fed, the ECB and the BoE persistently maintained negative real policy rates during the period, financial repression or otherwise. Even the BoJ managed to push its real policy rate into negative territory after 2013, as inflation rose in the wake of its 'quantitative and qualitative easing'. Some other central banks - the National Bank of Denmark, ECB and Swiss National Bank - even imposed outright negative nominal policy rates. In any case, China no doubt had the highest real policy rates among the five major central banks during this period.
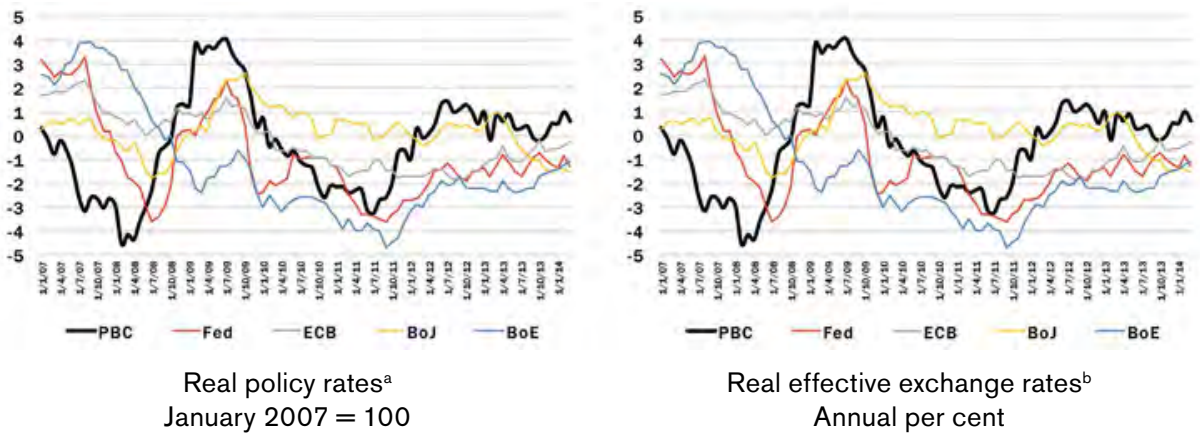

Figure 3.4 Real policy rates and real effective exchange rates for G5 central banks

a Policy rate less actual CPI inflation. The official ceiling for the one-year deposit rate is taken as the policy rate of the $\mathrm{PBC}$.

${ }^{\mathrm{b}} \mathrm{CNY}=$ Chinese renminbi; USD = US dollar; EUR = euro; JPY = Japanese yen; and GBP = British pound.

Sources: Datastream and BIS.

Of course, unconventional monetary policy went one step further to influence the long end of the yield curve. The exchange rates of the big four SDR currencies were thus indirectly influenced. In China's case, the PBC directly manages both its interest rate and its exchange rate, to some extent, given the still binding capital controls frustrating cross-border arbitrage (Ma and McCauley 2008, 2013). Either way, the real effective exchange rate serves to highlight another important aspect of monetary policy; and sustained and large movements in currencies redistribute growth across the globe.

The BIS real effective exchange rate data reveal that among the G5 currencies, only the Chinese renminbi (RMB) showed sizeable appreciation (35 per cent) from 2007 to mid-2014 (the right-hand panel of Figure 3.4). Meanwhile, the other four SDR member currencies (the dollar, euro, yen and sterling) had registered 5 per cent to 15 per cent real effective depreciation. Note that the yen appreciated noticeably between 2007 and 2012 until the start of the so-called 'Abenomics', but by March 2014 had weakened by 30 per cent from its peak in 2011. Since mid-2014, the divergent monetary policies of major central 
banks have led to broad and marked US dollar strength, pushing a still loosely dollar-anchored RMB even stronger in broad real effective terms (not shown in Figure 3.4). A much stronger and potentially overvalued RMB likely further redistributed growth away from China to the rest of the world.

Therefore, both the real policy rate and the real effective exchange rate suggest that the PBC maintained the most restrictive policy stance among the G5 central banks after the GFC. Among them, the BoE appears to have pursued the most aggressive monetary easing to date, and the $\mathrm{PBC}$ was by far the most restrained, until it more decisively embarked on a cycle of monetary relaxation from mid-2014 and the US Fed stopped its asset purchases.

What are the implications of a marked monetary tightening by the $\mathrm{PBC}$ relative to the four SDR central banks before its latest monetary policy shift? There are at least three as far as China is concerned.

First, China bore the brunt of the global demand and current account rebalancing from 2007 to 2014. Both rising domestic real interest rates and a strengthening real effective exchange rate have produced considerable pressures on the twin external and internal rebalancing. This tighter Chinese monetary policy stance has no doubt added significant deflationary headwinds to a slowing Chinese economy already experiencing a rapidly shrinking current-account surplus (Ma et al. 2012) and a marked weakening in domestic demand. Indeed, such a rapid adjustment in the Chinese current account balance itself could have been one important factor behind China's leveraging up in the past decade.

Second, this deflationary headwind was only partially countered by a massive credit binge that can be best viewed more as a quasi-fiscal stimulus than a proper monetary accommodation. China's relative monetary tightening thus could have aggravated its domestic imbalance, because much of this de facto fiscal stimulus funded hasty investment projects often undertaken by local governments and state firms. A timely and measured shift towards monetary relaxation would better cushion growth through those more market-based, though sometimes not very smooth, transmission channels.

Third, China's relatively tight monetary policy has probably absorbed much of the international spillover from the competitive monetary easing implemented by other major central banks, by not adding to the massive global monetary stimulus. This should in turn help dampen the volatility of those highly pro-cyclical capital flows to emerging markets and ease the competitive devaluation pressure globally. China has so far endured external deflationary shocks, acting as a source of global financial stability. 
The bottom line is that in the wake of the GFC, the PBC's stance was the most restrictive among the G5 central banks. In other words, the $\mathrm{PBC}$ was quite restrained, while the other big four central banks pursued more aggressive monetary accommodation. There is little doubt that the relatively tight Chinese monetary policy both redistributed global demand away from domestic to foreign products and weighed on Chinese domestic demand. Therefore, China ought to loosen its relatively tight monetary policy.

This global comparative framework can be taken one step further through the construction of a broader financial conditions index (FCI) for the same G5 economies and by asking whether China's financial conditions will be another suspect contributing to its marked growth slowdown on the demand side. The rationale is that whether a given monetary policy stance will have a similarly meaningful effect on economic agents depends in part on the transmission channels. An expansionary monetary policy might or might not help deliver a more relaxed financial environment for business and consumers.

Given a particular monetary policy stance, the functioning of a financial system itself matters for growth performance. Europe's half-asleep banking sector is a case in point. If the recent Chinese economic slowdown was primarily structural, more lax financial conditions would not help and might even worsen the structural problems that dragged down economic growth in the first place. Indeed, China in the past few years has witnessed weaker growth and rising credit as a ratio to GDP, in contrast with a 'credit-less recovery' in the euro area (Darvas 2013).

To this end, my proposed crude and simple FCI aims to capture the broader financial environment that could influence the behaviour of agents in the Chinese and big-four SDR economies, by focusing on the price aspect of the financial environment. It is a weighted sum of five key financial asset prices: policy rate, one-year treasury yield, 10-year treasury yield, effective exchange rate and benchmark stock market index. Higher readings denote tightness owing to the first three rates and the effective exchange rate, so I use the inverse of the stock market index to capture changes in equity prices.

I place an equal weight of 20 per cent on each of the z-scores of these five financial prices. Thus, increases in interest rates, the effective exchange rate and the inverse stock market index all result in a rise in the FCI, indicating a tightening of financial conditions. As in the discussion of G5 central bank monetary policy, I will focus on the post-crisis period from January 2007 to March 2014 before the latest Chinese monetary easing. A positive FCI reading thus suggests tighter financial conditions than the period average, while a negative reading indicates loosening. I consider two versions of the FCI: one based on nominal interest 
rates and the effective exchange rate, and the other on their real (ex post) counterparts. In this way, the Chinese FCI can be compared directly both over time and with its international peers, in real and nominal terms.

The central message from these G5 FCIs is that China's financial conditions tightened the most of the major economies from the start of the GFC (Figure 3.5). Also, China started with relatively lax financial conditions on the eve of the GFC, but post-2011 tightened considerably, at least until about mid-2014 when the PBC started loosening. In contrast, the financial conditions in the G4 generally became less stringent in the same period, as shown by both their nominal and their real FCIs.
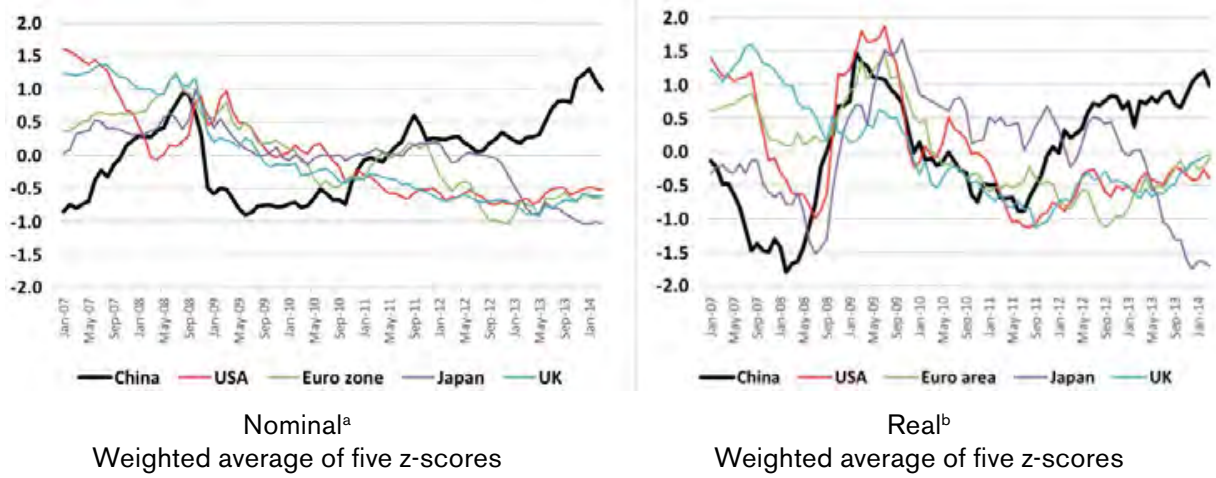

Figure 3.5 Financial condition indices (FCl) for $\mathrm{G} 5$ economies

${ }^{a}$ A rise suggests tightening. A positive number indicates tighter than the sample average. The official ceiling for the one-year deposit rate is taken as the policy rate of the PBC. The benchmark stock market indices are Shanghai Stock Exchange Composite Index for China, S\&P 500 for the United States, Nikkei 225 for Japan, FTSE 100 for the United Kingdom, and a market cap weighted average of CAC 40, DAX 30, IBEX 35, FTSE Mid and AEX (January 2007=100) for the euro area.

b The real interest rate and exchange rate are nominal rates adjusted for current CPI inflation. Sources: Datastream; BIS and author's calculation.

Moreover, all of the five asset prices underlying the Chinese FCI indicate an unmistakable financial tightening in this period: rising short and long-term interest rates, a strengthening RMB, and a languishing Shanghai stock market that lost 27 per cent of its value during this episode before its latest strong resurgence and stabilising government bond yields from the second half of 2014 .

Finally, the paths of the nominal and real FCIs have differed somewhat among these big-five economies in the post-2007 period, but all indicate tighter financial conditions in China over time and relative to its international peers between 2007 and mid-2014. While the real FCIs of the five major economies have shown noticeable swings, their nominal counterparts, except China, display steady, large and synchronised declines, indicating considerable easing of the financial conditions outside China. 
In sum, China's financial conditions were clearly the most restrictive during 2007-14 among the G5 economies. Intuitively, this revealed financial tightening - over time and relative to its international peers - could have meaningfully weighed on China's economy. Interestingly, our price-based FCI contrasts sharply with the observed Chinese credit surge in the wake of the GFC.

The tighter Chinese financial conditions could in part be policy-induced and in part relate to other institutional and fundamental changes in the Chinese economy, potentially contributing to slower economic growth. In any case, Chinese policymakers ought to take notice of such marked, sustained and broad-based tightness of the financial conditions. It would be very brave for anyone to claim that the tighter broad Chinese financial conditions had little to do with the recent Chinese economic slowdown. Suffice to say that a tighter broad financial environment tends to hurt private firms more and add to the financial woes of heavily indebted local governments in China. Therefore, as an insurance policy, China ought to ease its monetary policy.

Much more needs to be learned about the underlying causes of the more restrictive Chinese financial conditions against a background of falling growth and more liberal market environments. This task is beyond the scope of this chapter. For instance, a rigid 75 per cent regulatory cap on the bank loan-todeposit ratio and a punitive 20 per cent reserve requirement ratio might have added to financial tightness in the Chinese economy, prompting policymakers in Beijing to tweak these rules in an attempt to loosen the domestic financial conditions (Ma 2014b). Another, complementary possibility is that the PBC's easing remained behind the curve, as indicated by the Chinese business cycle.

All said, in the wake of the GFC, not only did the Chinese monetary policy stance tighten the most among the big-five central banks, but also the broader Chinese financial conditions became the most restrictive among the G5 economies. Thus, the case for Chinese monetary easing is also compelling in the global context.

\section{A perspective of optimal policy mix}

Finally, I will make a case for Chinese monetary easing within the framework of optimal monetary and fiscal policy. Two arguments are put forward-one from the perspective of an open macroeconomic model and the other from the perspective of domestic fiscal and monetary policy interaction.

First, a standard Fleming-Mundell model (Dornbusch 1976) postulates that under the assumptions of open capital account and exchange-rate flexibility, a combination of loose monetary policy and neutral fiscal policy would be the 
best way for China to contain external deflationary shocks, cushioning growth while introducing two-way market expectations and volatility of the RMB exchange rate and incremental capital opening.

Since mid-2014, the PBC has considerably scaled down its routine foreign exchange interventions and widened the onshore daily trading band of the RMB. Moreover, the Chinese capital account has become more open over time (Ma and McCauley 2008, 2013). The recent gathering pace of the RMB internationalisation can be viewed as capital opening by stealth (Cheung et al. 2011). Increased financial openness implies greater sensitivity of cross-border financial flows to price signals, which in turn will be influenced by the mix of monetary and fiscal policies.

So, what would be a sensible mix of fiscal and monetary policies in the context of a more open capital account, effectively appreciating and more flexible currency, weakening domestic demand and broad strength of the US dollar? As discussed below, China's overall central and local government fiscal policy stance is unlikely to be meaningfully expansionary in the next few years (Zhu 2015), therefore, a key policy choice is whether one should pursue relatively tight or loose monetary policy.

According to the classical Fleming-Mundell model, given a neutral fiscal policy, an expansionary monetary policy would discourage capital inflows and slow the broad-based appreciation of the RMB in today's global environment. A less appreciated $\mathrm{RMB}$ would therefore discourage swings in capital flows and support the ongoing difficult domestic rebalancing, while monetary easing directly cushions domestic demand. Thus, to facilitate growth, rebalancing and currency flexibility at the same time, China ought to ease monetary policy.

Therefore, an accommodative monetary policy and neutral fiscal policy can combine to best promote both economic growth and fuller exchange rate flexibility of the RMB, especially against a global backdrop of near-zero interest rates at major central banks.

What about the global environment of broad dollar strength that could trigger capital outflows from China, putting depreciation pressure on the RMB vis-avis an almighty US dollar? At the time of writing, the RMB has repeatedly been testing the weak side of the daily trading band, despite serious efforts by the PBC to signal a steadier RMB-US dollar rate via its daily fixing (Figure 3.6). If managed properly, this is a healthy adjustment in a substantially appreciated RMB for three reasons. 


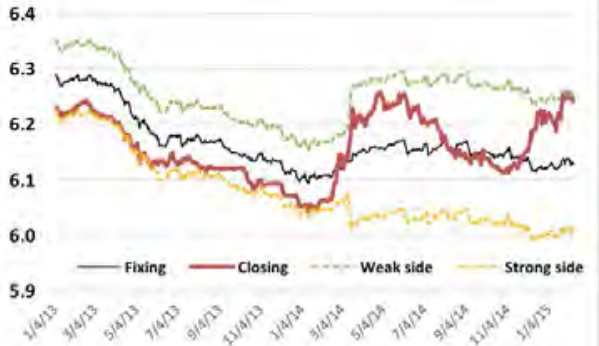

RMB per US\$a

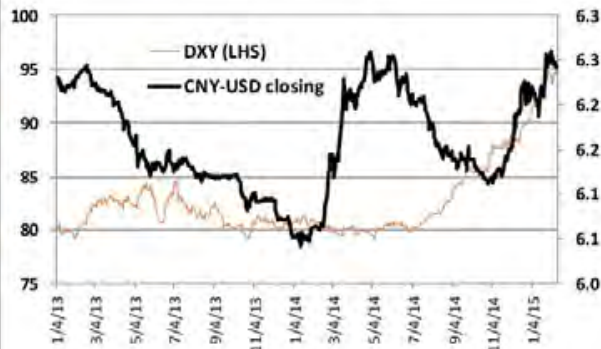

The US dollar index and the RMB-US $\$$ rate $^{\mathrm{b}}$

Figure 3.6 The RMB daily trading band and the US dollar index

a The daily trading band was \pm 1 per cent before March 2014 and \pm 2 per cent afterwards.

${ }^{b}$ The US dollar index is the US Fed narrow basket index. The RMB-US dollar is the number of RMB per US dollar.

Source: Bloomberg.

First, a very strong RMB should loosen its link to the US dollar. The RMB will probably continue strengthening on a broad real effective basis, despite the prospect of some near-term weakness vis-a-vis a strong US dollar. In 2014, the RMB depreciated 2.5 per cent against the dollar but gained 7 per cent in tradeweighted terms, according to BIS statistics. But the Chinese currency is likely to again outperform most advanced and emerging market currencies in 2015, remaining a source of global financial stability. More importantly, China should move further away from its loose dollar peg to gain policy autonomy under an increasingly open capital account.

Second, greater two-way volatility vis-a-vis the US dollar is a crucial step to move further away from the already loose dollar peg, which has historically served China well as a credible nominal anchor. Indeed, the Chinese inflation record has fared better under the dollar peg since 1994 than during 1978-93 (Amstad et al. 2014). But its time is up, as the Chinese economy has simply become too big to be anchored to the US dollar or any single currency alone, even in a loose fashion. Effective stability of the RMB better serves China's longterm interests (Ma and McCauley 2011).

Third, some dollar outflows would facilitate orderly currency movements, allowing Chinese corporations to hedge and extinguish their dollar liabilities and the official sector to trim its dollar assets. McCauley et al. (2015) estimate that the dollar debts of Chinese corporations could exceed US\$1.1 trillion. Shifting currency expectations owing to a mighty US dollar, a narrower than expected policy interest rate differential because of monetary policy divergence between China and the United States and possibly higher currency volatility given a less interventionist $\mathrm{PBC}$ have combined to result in a lower Sharpe ratio-an 
indicator of risk-adjusted returns. This in turn could prompt some unwinding of Chinese corporate carry trade to be funded in part by an orderly drawdown of the official reserves.

The next argument concerns the role fiscal policy can play in sharing the burden of cushioning economic growth and mitigating financial risk. My take is that a neutral fiscal policy stance might be the best course of action for policymakers in Beijing in the next few years, thus necessitating reasonable monetary accommodation.

With a slowing economy and weaker property market, the official fiscal policy should aim to avoid excessive tightening. First, the fiscal automatic stabilisers have already kicked in, as witnessed by a marked slowdown in overall Chinese tax revenues. Second, the Chinese Government has also undertaken selective tax and capital expenditure measures to fund infrastructure and affordable housing projects. Third, the Chinese official 2015 budget targets a deficit of 2.3 per cent of GDP compared with a 2014 out-turn of 1.8 per cent, and could actually reach a budget deficit of 2.6 per cent of GDP if the 2014 leftover budgetary funds are all to be spent in 2015 .

However, despite a low level of central government debt, of 15 per cent of GDP, the combined overall fiscal position of central and local governments has been much more challenging, with their combined debt level tripling to 45 per cent. There is a real moral hazard risk associated with China's high and unsustainable level of local government debt. Local government officials have strong incentives to borrow, from both banks and the shadow banking sector, to fund their pet investment projects, but then leave messy debts to their successors. With rising local government debts since the GFC, the pressure to restructure local government finance has also been mounting.

This trend has been aggravated by a structural mismatch between fiscal revenues and expenditure obligations between the central and local governments. The financing needs of local government have been an important driver of the expansion of shadow banking in recent years, partially offsetting the potential benefits promised by the ongoing interest rate deregulation. In the longer run, China needs to rebalance the fiscal revenue sharing and outlay obligations between the central and local governments (Ma and Wang 2010). In the short term, some practical ways must be found to balance ongoing financing needs and moral hazard concerns.

Since late 2013, most local governments in China have come under mounting cash-flow pressures, which are in part market-driven and in part policy-induced. First, a cooler Chinese property sector since 2013 has significantly slowed proceeds from land sales, which mostly accrue to local governments. Indeed, 
some localities might face the stark new reality of diminished availability of land for sale. Nationwide, the growth of government land sale proceeds has plunged since mid-2014. ${ }^{3}$

Second, the policy of the central government has been to gradually tighten local government budget constraints, by curtailing their borrowing via various financing vehicles, demanding greater transparency and disclosure of local fiscal conditions, and enhancing regulation of shadow banking.

These two factors have nevertheless combined and translated into a de facto sizeable but necessary fiscal contraction in the short term, which may not be fully offset by a slightly more expansionary 2015 official budget. This fiscal tightening most likely shows up as weaker local investment expenditure, whatever the official 'proactive' fiscal policy means. Thus, the overall de facto Chinese fiscal policy stance might still be somewhat contractionary and at best neutral in 2015, calling for reasonable monetary relaxation to partially offset the possible contractionary effects of reduced local government borrowing on the Chinese economy. This picture is unlikely to become brighter in the next two to three years.

Although concerns over fiscal dominance remain real, tighter monetary policy is neither a credible nor a helpful response to the risks of moral hazard and soft budget constraints related to Chinese local governments. On the contrary, monetary accommodation should help mitigate the contractionary impact of the tighter local government budgetary constraints in the short term and facilitate gradual restoration of fiscal discipline and rebalancing of central and local fiscal resources and responsibility in the longer term.

In sum, both the insights from the Fleming-Mundell model and the need to mitigate contractionary impacts of tighter local government financing call for a sensible policy mix of monetary relaxation and a neutral fiscal stance. Therefore, the latest monetary easing by the $\mathrm{PBC}$ is well justified - and more can be done.

\section{Conclusions}

Since mid-2014, the PBC has embarked on a cycle of monetary easing in an attempt to mitigate slowing growth, emerging deflationary pressure, tight domestic financial conditions, waning net capital inflows and the contractionary consequences of local fiscal restructuring. This chapter makes a strong case

3 Proceeds from land sales accrue mostly to local governments and have plummeted from 40 per cent yearon-year in the first quarter of 2014 to 26 per cent in the second quarter, 17 per cent in the third and just 3 per cent in the final quarter. The first quarter of 2015 witnessed a plunge of 43 per cent (Zhu 2015). 
that this shift in the Chinese monetary policy stance is warranted and desirable. Of course, whether Chinese monetary policy achieves its intended effects will depend on many factors outside the scope of this chapter, such as functioning transmission mechanisms.

Nevertheless, contrary to the view that monetary easing is a show of no confidence in reform, an act of sabotaging reform and/or a policy move that could worsen structural imbalances, a timely, measured but serious monetary policy accommodation is the best course of policy action that will serve the Chinese economy well in both the short term and the long term. Specifically, meaningful monetary easing helps cushion growth, support reform, facilitate rebalancing and mitigate financial stress.

First, prompt monetary relaxation, not tightening, supports domestic demand, reduces the headwinds from de facto fiscal contraction emanating from local government deleveraging, eases the relatively tight Chinese financial conditions and deflects global deflationary shocks. It helps mitigate adverse demand shocks, which have been non-trivial, and as a minimum, avoids rubbing salt into the wound.

Second, China's monetary policy accommodation can help accelerate liberalisation, by winning both broader political support and gaining greater headroom for implementing difficult reforms. While monetary policy is neither a magic bullet nor a substitute for the necessary institutional and structural reforms, monetary easing could provide the reform-minded PBC a window of opportunity to accelerate financial liberalisation. In contrast, maintaining tight monetary and fiscal policies as an ill-advised tactic to force through tough reform programs could be counterproductive, if not reckless.

Third, a timely monetary relaxation should help cushion an orderly slowdown of the Chinese economy, in turn facilitating the structural rebalancing task. The credit binge witnessed during the GFC was partially the consequence of the unmistakably late monetary policy response to collapsing domestic and external demand at that time. And this rapid credit expansion mostly funded local government investment, likely worsening domestic imbalances. Moreover, most of the credit allocation and industrial policy responsibilities burdening the PBC should be decommissioned, because monetary policy is not an apt instrument with which to address such structural issues.

Fourth, financial stability concerns have likely come to figure more prominently on the PBC's agenda because a key challenge is how to manage the legacy of excess leverage and increased financial imbalances in China. One sensible response is measured monetary accommodation to maintain steady nominal 
growth. This would help pre-empt a potentially vicious debt deflation cycle and dampen excess volatility in the financial system, while facilitating the tricky deleveraging process, not vice versa.

\section{References}

Ajello, A., Laubach, T., L'opez-Salido, D. and Nakata, T. (2015), Financial stability and optimal interest-rate policy, Federal Reserve Board paper presented at the Federal Reserve Bank of San Francisco conference 'The New Normal for Monetary Policy', San Francisco.

Amstad, M., Huan, Y. and Ma, G. (2014), Developing an underlying inflation gauge for China, BIS Working Paper No. 465, September, Basel: Bank for International Settlements.

Bank for International Settlement (BIS), an international organisation that also provides regular data and statistics.

Blagrave, P., Garcia-Saltos, R., Laxton, D. and Zhang, F. (2015), A simple multivariate filter for estimating potential output, IMF Working Paper No. 15/79, Washington, DC: International Monetary Fund.

Bloomberg, a standing online commercial data and news service provider.

CEIC, a standing online commercial data service provider.

Cheung, Y.W., Ma, G. and McCauley, R. (2011), Renminbising China's foreign assets, Pacific Economic Review, 16(1): 1-17.

Claeys, G. and Darvas, Z. (2015), The financial stability risks of ultra-loose monetary policy, Bruegel Policy Contribution No. 2015/03, March, Brussels: Bruegel.

Claeys, G., Darvas, Z., Merler, S. and Wolff, G. (2014), Addressing weak inflation: The European Central Bank shopping list, Bruegel Policy Contribution No. 2014/05, May, Brussels: Bruegel. Available from: www.bruegel.org/ publications/publication-detail/publication/826-addressing-weak-inflationthe-european-central-banks-shopping-list/.

Darvas, Z. (2013), Can Europe recover without credit?, Bruegel Policy Paper No. 2013/03, Brussels: Bruegel.

Datastream, a standing online commercial data service provider.

Dornbusch, R. (1976), Exchange rate expectations and monetary policy, Journal of International Economics, 6(3): 231-44. 
Girardin, E., Lunven, S. and Ma, G. (2014), Understanding the monetary policy rule in China: What is the role of inflation?, in Globalisation, inflation and monetary policy in Asia and the Pacific, BIS Papers No. 77, March, Basel: Bank for International Settlements, pp. 159-70.

Iwata, K. and Takenaka, S. (2012), Central bank balance sheets expansion: Japan's experience, JCER Discussion Paper No. 134, Tokyo: Japan Centre for Economic Research.

Ma, G. (2014a), Guest post: Should China cut interest rates?, Financial Times, 9 July. Available from: blogs.ft.com/beyond-brics/2014/07/09/guest-postshould-china-cut-interest-rates/.

Ma, G. (2014b), Tweaking China's loan-deposit ratio rule, Bruegel Blog, Brussels: Bruegel. Available from: www.bruegel.org/nc/blog/detail/article/1425tweaking-chinas-loan-deposit-ratio-rule/.

Ma, G. (2015), Backward guidance, Chinese style, Bruegel Blog, Brussels: Bruegel. Available from: www.bruegel.org/nc/blog/detail/article/1541-backwardguidance-chinese-style/.

Ma, G. and McCauley, R. (2008), The efficacy of China's capital controls: Evidence from price and flow data, Pacific Economic Review, 13(1): 104-23.

Ma, G. and McCauley, R. (2011), The evolving renminbi regime and implications for Asian currency stability, Journal of the Japanese and International Economies, (25)(March): 23-38.

Ma, G. and McCauley, R. (2013), Is China or India more financially open?, Journal of International Money and Finance, (39): 6-27.

Ma, G. and Wang, Y. (2010), China's high saving rate: Myth and reality, International Economics, (122): 5-40.

Ma, G., McCauley, R. and Lam, L. (2012), Narrowing China's current account surplus: The roles of saving, investment and the renminbi, in McKay, $\mathrm{H}$. and Song, L. (eds), Rebalancing and sustaining growth in China, Canberra: ANU E Press, pp. 65-91.

Ma, G., Yan, X. and Xi, L. (2012), China's reserve requirements: Practices, effects and implications, China Economic Policy Review, 1(2): 1-34. Ma, J. and Hong, H. (2015), The impacts of the structural factors on the long term growth potential of the Chinese economy: A DSGE model analysis, Draft.

McCauley, R., McGuire, P. and Sushko, V. (2015), Global dollar credit: Links to US monetary policy and leverage, BIS Working Papers No. 483, January, Basel:

Bank for International Settlements. 
Morley, J. (2014), Measuring economic slack: A forecast-based approach with applications to economies in Asia and the Pacific, BIS Working Paper No. 451, Basel: Bank for International Settlements.

Nakamura, E., Steinsson, J. and Liu, M. (2015), Are Chinese growth and inflation too smooth? Evidence from Engel curves, Discussion Paper, New York: Columbia University.

Rajan, R. (2014), Competitive monetary easing: Is it yesterday once more?, Speech by Governor of Reserve Bank of India at the Brookings Institution, 10 April, Washington, DC.

Sina Finance (2014), China Xinhau News and People's Daily debate over the controversial relationships between interest rate cuts and economic reform, Sina Finance [in Chinese], 17 September. Available from: finance.sina.com. cn/china/hgjj/20140917/165620320384.shtml.

Svensson, L. (2015), Discussion, Federal Reserve Bank of San Francisco conference 'The New Normal for Monetary Policy', San Francisco.

Tanaka, O. (2010), China's macroeconomic policy shift in 2008: Political process from tightening to easing, Public Policy Review, 6(3), Tokyo: Policy Research Institute, Ministry of Finance.

Taylor, J. (1993), Discretion versus policy rules in practice, Carnegie-Rochester Conference Series on Public Policy, 39: 195-214.

Zhu, H. (2015), China: Will fiscal policy be expansionary in 2015?, JP Morgan Economic Research Note, New York: JP Morgan. 
This text is taken from China's Domestic Transformation in a Global Context, edited by Ligang Song, Ross Garnaut, Cai Fang \& Lauren Johnston, published 2015 by ANU Press, The Australian National University, Canberra, Australia. 